\title{
RESUMPTION ANd LAST RESORT ${ }^{*}$ \\ (Pronomes Resumptivos e a Condição de Último Recurso)
}

\author{
Joseph Aoun \\ (University of Southern California)
}

ABSTRACT: This paper discusses the derivation of definite and indefinite relative clauses in Lebanese Arabic. The two types of relative clause are similar in that they require resumptive pronouns and do not exhibit island effects. Based on reconstruction effects, I however argue that definite relatives may be either base-generated or derived by movement, whereas indefinite relatives can only be base-generated.

KEY WORDS: Relative Clauses, Resumptive Pronouns, Reconstruction, Lebanese Arabic

RESUMO: Este trabalho discute a derivação de orações relativas definidas e indefinidas em árabe libanês. Os dois tipos de relativas são semelhantes na medida em que ambos requerem pronomes resumptivos e não exibem efeitos de ilha. Com base em efeitos de reconstrução, eu argumento no entanto que as relativas definidas podem ser tanto geradas na base, quanto derivadas por movimento, enquanto as relativas indefinidas só podem ser geradas na base. PalaVRas-Chave: Orações Relativas, Pronomes Resumptivos, Reconstrução, Árabe Libanês

\section{Introduction}

The goal in this paper is to investigate some properties of resumptive pronouns in Lebanese Arabic (henceforth, LA). ${ }^{1}$ I will do so by investigating the behavior of restrictive relative constructions in LA, which are generated with the resumptive strategy. ${ }^{2}$

\footnotetext{
* For his comments on an earlier draft of this paper, I wish to thank Jairo Nunes. This paper was completed in the spring of 1996.

1 Issues related to weak crossover and resumption are discussed in Aoun and Choueiri (1996). Different analyses of weak crossover with constructions involving resumptives can be found in Demirdache (1991, to appear), Georgopoulos (1989), McCloskey (1990), Safir (to appear), and Sells (1984).

2 The topic of resumption has been the center of numerous studies. I have mainly relied on work done by the following authors: Borer (1983), Cinque (1990), Demirdache (1991), Doron (1983), Eid (1977, 1983), Engdhal (1986), McCloskey (1990), Sells (1984), Shlonsky (1992), and Zaenen, Engdahl, and Maling (1981).
} 
LA distinguishes between definite relative constructions and indefinite ones. Definite relatives are generated with a definite complementizer; indefinite relatives are generated with no complementizer.

(1) a. Definite relativized $\mathrm{DP}_{\mathrm{i}}$.. definite complementizer .. resumptive element b. Indefinite relativized DP resumptive element

The following generalizations hold true in LA:

(2) a. all relative constructions may violate islands.

b. definite relatives display reconstruction only when the resumptive clitic does not occur within an island.

c. indefinite relatives do not display reconstruction.

Simplifying the features of the analysis, the behavior of the two types of relatives is accounted for under the following assumptions:

(3) a. movement is available in definite relatives

b. movement is not available in indefinite relatives

In definite relatives, movement is triggered to check features of the complementizer. In indefinite relatives, on the other hand, there is no complementizer and nothing forces movement to occur. As such, it does not occur. In other words, in LA, movement in relative constructions appears to be a last resort strategy.

The theoretical implications of the analysis of resumptives will be discussed in the conclusion.

\section{Restrictive relatives in Lebanese Arabic}

As stated in the introduction, restrictive relative clauses in LA fall into two categories: restrictive relatives with a definite relativized DP (definite relatives) and restrictive relatives with an indefinite relativized DP (indefinite relatives). ${ }^{3}$

3 In this paper, I restrict our investigation of relative constructions in LA to restrictive relatives. I will henceforth refer to them using the general term relative clause. 
Definite relatives always occur with the complementizer yalli: ${ }^{4}$

(4) a. 1-kteeb *(yalli) ' tarayto mbeerif Daa the-book that bought.1S-it yesterday is-lost.3SM

'The book that I bought yesterday is lost.'

b. tPaaSaS 1-walad *(yalli) (huwwe) xazza? 1-kteeb punished.3SM the-boy that (he) tore.3SM the-book 'The boy that tore up the book was punished.'

Indefinite relatives on the other hand cannot occur with yalli; as a matter of fact, indefinite relatives have no complementizer:

(5) a. \am fatti' \a kteeb (*yalli) Dayyaft-o 1-yom Asp look.1S for book that lost.1S-it today 'I am looking for a book that I lost today.'

b. Sam fatti' \{a walad (*yalli) Darab kariim Asp look.1S for boy that hit.3SM K. 'I am looking for a boy that Zeina said hit Karim.'

What unifies these two types of relatives is that they are both formed with the resumptive strategy: in constructions with definite relatives and indefinite relatives, the relativized DP is generally related to a resumptive element that occurs within the relative clause. In non-subject positions, ${ }^{5}$

4 yalli is specific to relative constructions. Sentential complements in LA are introduced by Pənno, as illustrated below:

(i) 1-bənt yalli/*?ənno 2eebit $\min$ SSaff mbeerif rə3 亿it the-girl that was-absent.3SF from the-class yesterday returned.3SF

'The girl that was absent from class yesterday returned.'

(ii) Paalit 1-mfallme Pənno/*yalli 1-bənt 1-2eeybe rə3 Sit said.3SF the-teacher that the-girl the-absent returned.3SF

'The teacher said that the absent girl returned.'

5 These non-subject positions include complements of verbs as well as complements of prepositions (i) or nouns (ii).

(i) a. 'tarayt 1-kteeb yalli fikiite bought.1S the-book that talked.2S about-it yesterday 'I bought the book that you talked about yesterday.'

b. Sam fatti $\{$ a-kteeb $\chi$ abbir ttlemiiz \{anno Asp look.1S for-book tell.1S the-students about-it 'I am looking for a book to talk to the students about.' 
the resumptive element is always realized as a clitic (or weak pronoun) (4a-5a). In subject position, the resumptive element may be realized as a tonic (or strong) pronoun (4b). ${ }^{6}$ In what follows, I investigate the resumptive strategy in both definite relatives and indefinite relatives.

\subsection{Resumption in definite relatives}

In definite relatives, gaps are prohibited in all non-subject positions. Instead, the relativized position is occupied by a resumptive clitic (6-7).

(6) 'əfna l-bənt yalli hannət-*(a)

1-mfallme

saw.1P the-girl that congratulated.3SF-*(her) the-teacher

'We saw the girl that the teacher congratulated.'

(7) 'əfna 1-bənt yalli ?aal kariim ?ənno hannət-*(a) saw.1P the-girl that said.3SM K. that congratulated.3SF-*(her) 1-miallme the-teacher

'We saw the girl that Karim said that the teacher congratulated.'

As (6) and (7) show, the resumptive clitic is required both in the higher object position and the embedded object position within the definite relative.

$\begin{array}{ll}\text { (ii) a. 'tarayt } 1 \text {-kteeb yalli btairfe } & \text { keetbo } \\ \text { bought.1S the-book that know.2SF writer-his } \\ \text { 'I bought the book that you know its writer.' }\end{array}$

b. fDrna masrafiyye btafrif muxriza laila

saw.1P play know.1SF director-its L.

'We saw a play that laila knows its director.'

I will illustrate our generalizations using constructions with accusative resumptive clitics. However, these generalizations hold true of resumptive clitics which are complements of prepositions and nouns as well.

6 In this paper I will deal only with restrictive relatives involving resumptive clitics. The reader is referred to Aoun and Choueiri 1996 and Aoun, Choueiri, and Hornstein 1998 for a discussion of strong pronouns that occur as resumptive elements. For an evaluation of the difference between strong and weak pronouns in null subject languages, the reader is referred to Kato (1999). It should be noted that the analysis argued for in this paper may be extended to cases of resumption involving strong pronouns. 
In subject position, a gap generally occurs:

(8) a. 1-mfallme PaaSaSit l-walad yalli Darab laila the-teacher punished.3SF the-boy that hit.3SM L. 'The teacher punished the boy that hit Laila.'

\begin{tabular}{|c|c|c|c|c|c|}
\hline 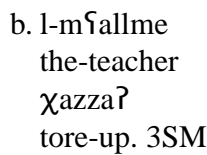 & $\begin{array}{l}\text { PaaSaSit } \\
\text { punished.3SF } \\
\text { l-kteeb } \\
\text { the-book }\end{array}$ & $\begin{array}{l}\text { 1-walad } \\
\text { the-boy }\end{array}$ & $\begin{array}{l}\text { yalli } \\
\text { that }\end{array}$ & $\begin{array}{l}\text { laila } \\
\text { L. }\end{array}$ & $\begin{array}{l}\text { Paalit } \\
\text { said.3SF }\end{array}$ \\
\hline
\end{tabular}

The gap in subject can be identified as an instance of pro-drop, which is generally available in LA. It can occur, for instance, in the following contexts, which block movement:

(9) a. Adjunct Island

laila bta\{rif l-walad yalli 1-mfallme fallit ?abl ma

L. knows.3SF the-boy that the-teacher left.3SF before

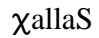

finished.3SM

'Laila knows the boy that the teacher left before he finished.'

b. Wh-Island

1-mfallme ?aaSaSit 1-walad yalli laila btafrif miin the-teacher punished.3SF the-boy that L. know.3SF who

Darab

hit.3SM

'The teacher punished the boy that Laila knows whom he hit.'

\section{c. Complex-NP Island}

ţarrafna Sala 1-muxri3 yalli laila 'eefit 1-masrafiyye yalli met.1P on the-director that L. saw.3SF the-play that Paxraza

directed.3SM-it

'We met the director that Laila saw the play that he directed.'

In (9a-c), a gap can occur in subject position within islands, which are know to disallow wh-extraction.

Similarly, the relation between a resumptive clitic and the definite relativized DP is not sensitive to islands, as illustrated in (10-12). 
(10) Adjunct Island

hkiina maf 1-muxriz yalli fallit laila Pabl ma $\mathrm{t}^{\mathrm{t}} \mathrm{uuf}-*(\mathrm{o})$ talked.1P with the-director that left L. before see.3SF-*(him) 'We talked to the director that Laila left before she saw him.'

(11) Wh-Island

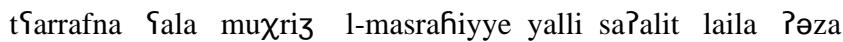
met.1P on director the-play that asked L. whether habbaynee-*(ha) liked.1P-*(it)

'We met the director of the play that Laila asked whether we liked it.'

(12) Complex-NP Island

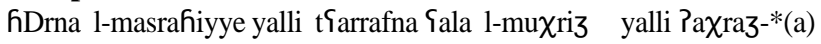
saw.1P the-play that met.1P on the-director that directed.3SM-*(it) 'We saw the play that we met the director that directed it.'

Adopting the standard assumption that the absence of island effects indicates the absence of movement, it is possible to account for the distribution of resumptive pronouns within definite relatives in LA by generating those constructions without movement. In what follows, I examine how this account extends to indefinite relatives.

\subsection{Resumption in indefinite relatives}

Like definite relatives, indefinite relatives also require a resumptive clitic in all non-subject positions (13-14).

(13) Sam tfatti' 1-m \{allme $\{a$ kteeb ma Pəryu-*(u) ttlemiiz Asp look.3SF the-teacher for book not read.3P-*(it) the-students 'The teacher is looking for a book that the students haven't read.'

(14) Sam tfatti' 1-m\{allme \{a kteeb ?aalit 1-mudiira Pənno ma Asp look.3SF the-teacher for book said the-principal that not Pəryu-*(u) ttlemiiz read.3P-*(it) the-students

'The teacher is looking for a book which the principal said that the students haven't read.'

In subject positions (15a-b) instead, a gap occurs: 
(15) a. Sam tfatti' 1-m Sallme \{a-walad bifiəbb yə?ra Asp look.3SF the-teacher for-boy like.3SM read.3SM 'The teacher is looking for a boy who likes to read.'

b. Sam tfatti' 1-m\{allme \{a-walad badda 1-mudiira Asp look.3SF the-teacher for-boy want.3SF the-principal yfəbb yə?ra like.3SM read.3SM

'The teacher is looking for a boy that the principal wants him to like to read.'

As can be observed in (16-18) below, the relation between the indefinite relativized DP and the resumptive element is not sensitive to islands:

(16) Adjunct Island

a. fkiina maS muxriz fallit laila ?abl ma $t^{\prime}$ uuf-*(o) talked.1P with director left.3SF L. before see.3SF-*(him) 'We talked to a director that Laila left before she saw.'

b. t\{arrafna \{ala muxri3 fallit laila ?abl ma yifke mafa met.1P on director left.3SF L. before talk.3SM with-her 'We met a director that Laila left before he talked to her.'

(17) Wh-Island

a. t\{arrafna Sala muXri3 ma mnafrif ?əza nnə??aad byəftərmu-*(u) met.1P on director not know.1P whether the-critics respect.3P-*(him) 'We met a director that we don't know whether the critics respect him.'

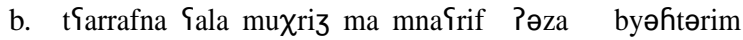
met.1P on director not know.1P whether respect.3SM nnə??aad the-critics

'We met a director that we don't know whether he respects the critics.'

\section{(18) Complex-NP Island}

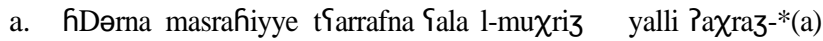
saw.1P play met.1P on the-director that directed.3SM-*(it) 'We saw the play that we met the director that directed it.'

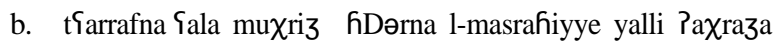
met.1P on director saw.1P the-play that directed.3SM-it 'We met a director that we saw the play that he directed.' 
Since it occurs in island contexts (16b-18b), the gap in subject position within the indefinite relatives can be identified as the null pronominal element pro. Indefinite relatives pattern together with definite relatives in allowing resumptive pronouns to occur within islands. It is therefore possible to generalize the analysis put forward for definite relatives to include indefinite relatives; in this case, indefinite relatives would also be generated without involving movement.

\section{Restrictive relatives in LA and movement: reconstruction effects}

The discussion in the previous section highlighted the absence of island effects within restrictive relatives in LA. It was suggested that this characteristic indicates that the derivation of restrictive relatives does not involve movement. This being the case, we expect relative clauses in LA not to display any effects of movement. In what follows, I show that this expectation is not always fulfilled and that movement may be involved in the generation of relative clauses in LA.

\subsection{Reconstruction within definite relatives}

In Chomsky 1993, it is argued that reconstruction is a property of chains generated by (non-L-related or A'-) movement. In view of the non-movement analysis suggested above, we expect definite relatives in LA never to display reconstruction effects; as can be observed below, this expectation is not always fulfilled.

(19) a. 'əft [SSuura tabå Pəbn- $\left.a_{\mathrm{i}}\right]_{\mathrm{j}}$ yalli $[\text { kəll mwazzafe }]_{\mathrm{i}}$ saw.1s [the-picture of son-her] that [every employee.f] Paalit Pənno badda t Sallə? $-\mathrm{a}_{\mathrm{j}}$ bi-maktab-a said.3sf that want.3sf hang.3sf-it in-office-her 'I saw the picture of her son that every employee said she wants to hang in her office.'

b. 'əft [SSuura taba؟ ?əbn- $\left.\mathrm{a}_{\mathrm{i}}\right]_{\mathrm{j}}$ yalli [kəll mwazzafe $]_{\mathrm{i}}$ saw.1s [the-picture of son-her] that [every employee.f] badda t\{allə? $-\mathrm{a}_{\mathrm{j}}$ bi-maktab-a want.3sf hang.3sf-it in-office-her 'I saw the picture of her son that every employee wants to hang in her office.' 
c. 'əft [SSuura tabaf Pəbn- $\left.\mathrm{a}_{\mathrm{i}}\right]_{\mathrm{j}}$ yalli Pəlto Pənno [kəcll wazzafe $]_{\mathrm{i}}$ saw.1s [the-picture of son-her] that said.3p that [every mployee.f] badda thallə? a $_{\mathrm{j}}$ bi-maktab-a want.3sf hang.3sf-it in-office-her 'I saw the picture of her son that you said that every employee wants to hang in her office.'

The sentences in (19) can be represented as in (20a-b) (irrelevant details omitted):

(20)
a. $\quad \cdots . .\left[_{\mathrm{DRel}-\mathrm{DP}}\right.$
$\operatorname{pron}_{\mathrm{i}} \ldots . .$.
]$_{\mathrm{j}} \ldots \ldots$
[ yalli ...
$\mathrm{QP}_{\mathrm{i}} \ldots\left(\left[_{\mathrm{CP}}\right) \ldots . . \mathrm{RP}_{\mathrm{j}} \ldots\right] \ldots \ldots$
b. $\quad \cdots . .\left[_{\text {DRel-DP }}\right.$
pron $\left._{\mathrm{i}} \ldots ..\right]_{\mathrm{j}} \ldots \ldots .\left[\right.$ yalli $\ldots . . . \mathrm{C}_{\mathrm{CP}}$ $\left.\left.\mathrm{QP}_{\mathrm{i}} \ldots \mathrm{RP}_{\mathrm{j}} \ldots\right]\right] \ldots . .$.

In (19), the pronoun contained within the definite relativized DP SSuura taba \& ?əbn-a 'the picture of her son' can be bound from within the relative clause by the QP kəll mwazzafe 'every employee'. This bound reading is represented in (20a-b) by coindexing the pronoun with the QP. The availability of the bound pronoun reading may be taken to indicate that the pronoun within the definite relativized DP is interpreted from the position of the resumptive pronoun, a position which is ccommanded by the QP kəll mwazzafe 'every employee'.

However, reconstruction is not always available: for instance, reconstruction is not available when the definite relativized DP and the resumptive element to which it is related are separated by an island (21-23).

\section{(21) Complex-NP Islands}

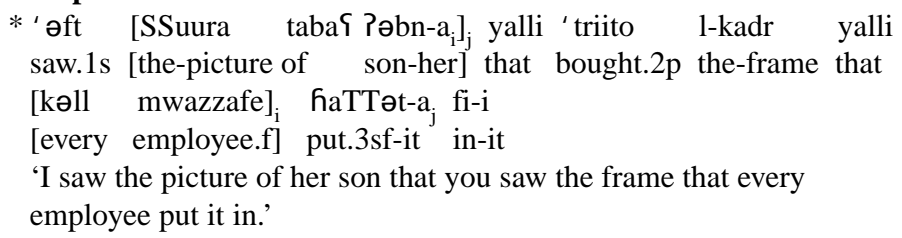

7 I will discuss how this interpretation obtains in section 3.3.2. 
(22) Adjunct Islands

* ‘əft [SSuura tabaโ Pəbn- $\left.\mathrm{a}_{\mathrm{i}}\right]_{\mathrm{j}}$ yalli z \{əlto la?anno [kəll saw.1s [the-picture of son-her] that upset.2p because [every

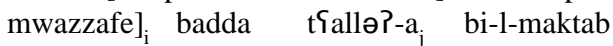
employee.f] want.3sf hang.3sf-it in-the-office 'I saw the picture of her son that you were upset because every employee wants to hang it in the office.'

(23) Wh-Islands

* 'əft [SSuura tabaৎ ?əbn- $\left.\mathrm{a}_{\mathrm{i}}\right]_{\mathrm{j}}$ yalli baddkun ta\{rfo ween saw.1s [the-picture of son-her] that want.2p know.2p where [kəll mwazzafe $]_{\mathrm{i}}$ badda t\{allə? $-\mathrm{a}_{\mathrm{j}}$ [every employee.f] want.3sf hang.3sf-it

'I saw the picture of her son that you want to know where every employee wants to hang it.'

The sentences in (21-23) have the representation in (24) (irrelevant details omitted):

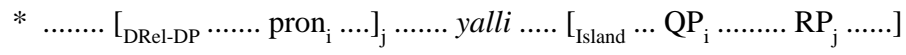

As indicated by the ungrammaticality of (24), the bound reading of the pronoun contained within the definite relativized DP SSuura taba S P $\partial b n-a$ 'the picture of her son' cannot obtain. That is, at LF the relativized DP containing the pronoun cannot reconstruct to a position c-commanded by the QP kəll mwazzafe 'every employee'.

Summarizing, we have observed in this section, that reconstruction is available in definite relatives when the resumptive element does not occur within an island. This generalization is illustrated in (25):

(25) a. Reconstruction available Relativized DP yalli ....... $\mathrm{RP}_{\mathrm{i}}$

b. No reconstruction available Relativized $\mathrm{DP}_{\mathrm{i}}$ yalli ..... $\left[\left[_{\text {Island }} \ldots \mathrm{RP}_{\mathrm{i}} \ldots.\right]\right.$

At this point, it is possible to assume that reconstruction is only tied to islands: that is, reconstruction effects occur when no island intervenes between the relativized DP and the RP to which it is related. Alternatively, one may assume, as I have done so far, that reconstruction is tied to movement. Under the latter assumption, the selective availability 
of reconstruction in definite relatives in LA indicates that movement is available for the generation of those constructions only when the island constraints are not violated: a derivation involving movement is thus available for the representation in (25a), but not for the one in (25b).

The working of reconstruction in indefinite relatives will provide motivation for the second assumption. It will appear that with indefinite relatives corresponding to the representation in (26), reconstruction is not available: Indefinite Relativized DP $\mathrm{RP}_{\mathrm{i}}$

The contrast between (25a) and (25b) shows that the absence of islands is a necessary condition for the availability of reconstruction. The unavailability of reconstruction in (26) will indicate that this condition is not sufficient to account for the cases in which reconstruction does in fact occur. Hence the assumption that reconstruction is tied to movement.

\subsection{Reconstruction within indefinite relatives}

As stated in the preceding paragraph, indefinite relatives do not display any reconstruction effects. That is, a pronoun contained within an indefinite relativized DP can never be bound by a QP in the indefinite relative clause. This generalization is illustrated below:

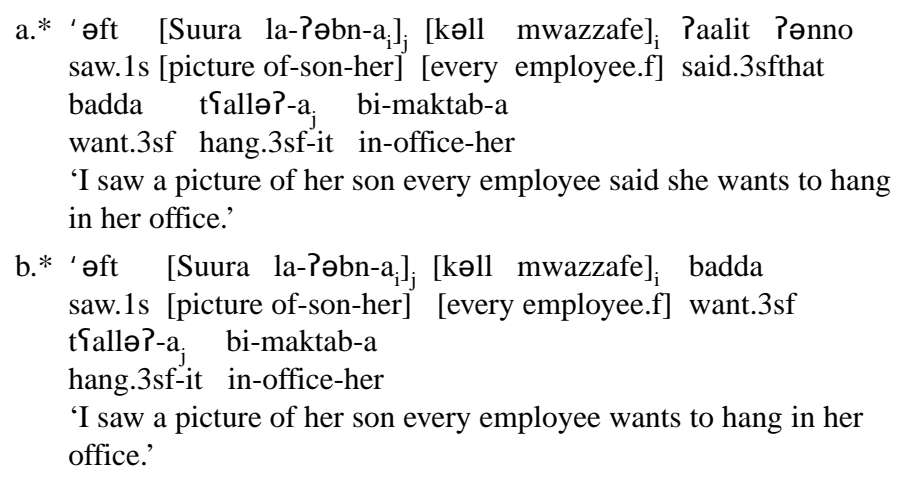




$$
\begin{aligned}
& \text { c.* 'əft [Suura la-Pəbn- } \left.\left.\mathrm{a}_{\mathrm{i}}\right]_{\mathrm{j}} \text { Pəlto Pənno [kəll mwazzafe }\right]_{\mathrm{i}} \\
& \text { saw.1s [picture of-son-her] said.3p that [every employee.f] } \\
& \text { badda t\{allə? }-\mathrm{a}_{\mathrm{j}} \text { bi-maktab-a } \\
& \text { said.3sfthat want.3sf hang.3sf-it in-office-her } \\
& \text { 'I saw a picture of her son you said that every employee wants to }
\end{aligned}
$$

The facts illustrated in (27) may be represented as in (28a-b) respectively:

$$
\begin{aligned}
& \text { a. }{ }^{*} \ldots \ldots . .\left[_{\text {IRel-DP }} \ldots \ldots . \operatorname{pron}_{\mathrm{i}} \ldots\right]_{\mathrm{j}} \ldots \ldots \ldots . . \mathrm{QP}_{\mathrm{i}} \ldots \ldots . .\left(\left[_{\mathrm{CP}}\right) \ldots . \mathrm{RP}_{\mathrm{j}} \ldots \ldots . .\right. \\
& \text { b.* } \ldots \ldots . .\left[_{\text {IRel-DP }} \ldots \ldots . \operatorname{pron}_{\mathrm{i}} \ldots\right]_{\mathrm{j}} \ldots \ldots .\left[_{\mathrm{CP}} \ldots . \mathrm{QP}_{\mathrm{i}} \ldots \ldots . \mathrm{V}+\mathrm{RP}_{\mathrm{j}} . .\right] \ldots . .
\end{aligned}
$$

Even when the RP does not occur in an island, the indefinite relativized DP with which this RP is coindexed cannot reconstruct below the QP in the indefinite relative (27). The contrast between definite relatives and indefinite relatives with respect to reconstruction, i.e. the contrast between (28) and (25), is accounted for under the assumptions that reconstruction is tied to movement and that no movement is involved in the generation of indefinite relatives. ${ }^{8}$ In what follows, I offer an

8 Obviously, indefinite relatives do not display reconstruction effects when the indefinite relativized DP is related to a resumptive element which occurs in an island:

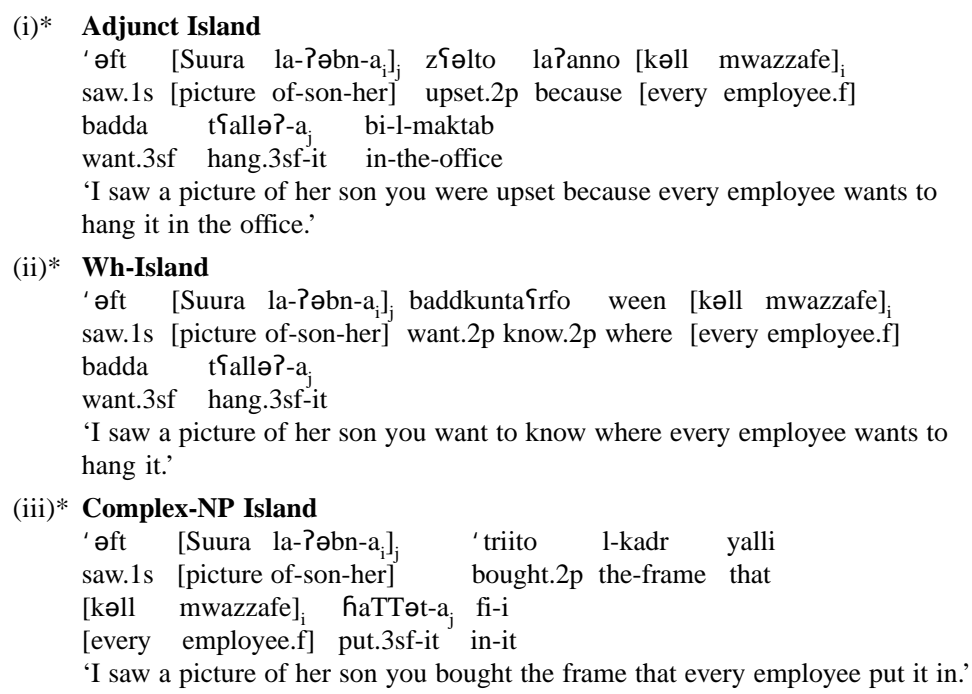


account for the discrepancy between definite relatives and indefinite relatives with respect to the availability of movement.

\section{Generation of definite relatives}

An analysis which allows movement in the derivation of definite relatives but not indefinite relatives raises the following questions:

(29) a. What triggers movement in definite relatives?

b. What is the nature of the moving element?

c. What is the landing site of this movement?

d. Why isn't movement available for indefinite relatives?

I start by investigating the properties of definite relatives.

\subsection{Morphosyntactic properties of yalli}

As noted earlier, the morpheme yalli occurs only in restrictive relatives that are definite, and is itself definite, as the following discussion indicates. $^{9}$

In LA, nouns and their modifiers agree in definiteness (30).

(30) a. 1-kteeb 1-3diid wəSil \{al-maktabe the-book the-new arrived at-the-bookstore

'The new book arrived at the bookstore.'

b. Sam fatti ${ }^{\prime}$ \{a kteeb 3diid PəPraa

Asp look.1S for book new read.1S-it

'I am looking for a new book to read.'

9 The counterpart of yalli in Standard Arabic ( $\mathrm{Pa}$ )llaD occurs in definite relatives but not in indefinite relatives. It is morphologically definite: it is introduced by the definite article $a l$ -

(i) qara?tu 1-kitaaba *(1laD) 'taraytu-hu 1-baarifa

read.1S the-book that bought.1S-it yesterday

'I read the book that I bought yesterday.'

(ii) qara?tu kitaaban (*llaD) 'taraytu-hu 1-baarifa

read.1S book that bought.1S-it yesterday

'I read a book that I bought yesterday.' 
In (30a-b), the adjectives agree in definiteness with the nouns they modify: In (30a), the adjective $l$-3diid (the new) occurs with the definite article $a l$ - since the noun it modifies, i.e. l-kteeb (the book), is definite. On the other hand, the adjective 3 diid (new) in (30b) does not occur with the definite article $a l$ - since the noun it modifies, i.e. kteeb (book), is indefinite.

Furthermore, a sentence where the noun and its modifier do not show agreement in definiteness would be ungrammatical:

(31) a.* 1-kteeb 3diid wəSil \{al-maktabe the-book newarrived at-the-bookstore 'The new book arrived at the bookstore.'

$\begin{array}{llll}\text { b. } & \text { Sam fatti' } \text { \{a kteeb 1-3diid } & \text { PəPraa } \\ \text { Asp look.1S for book the-new } & \text { read.1S-it } \\ \text { 'I am looking for a new book to read.' } & \end{array}$

Consider now the following sentences involving relative clauses:
a. 1-kteeb yalli Talabtii wəSil \{al-maktabe the-book that ordered.2SF-it arrived.3SM at-the-bookstore 'The book that you ordered arrived at the bookstore.'
b.* badde kteeb yalli yə?dro l-wleed yə?ruu want.1S book that can.3P the-children read.3P-it 'I want a book that the children can read.'

The contrast between (32a) and (32b) indicates that yalli is definite: yalli can only occur when the relativized DP is definite. Assuming yalli to be a complementizer generated in the head $\mathrm{C}$ of the relative clause, this would mean that the relative clause yalli Talabtii (that you ordered) in (32a) is definite, thus matching the relativized DP l-kteeb (the book). The ungrammaticality of (32b) is the result of the clash between the definiteness of the relative clause and the indefiniteness of the relativized DP.

In addition to being [+definite], yalli also bears $\varphi$-features. Generally, null subjects in LA occur in the context of overt agreement, as illustrated below: 
(33) a. raafit

left.3FS

'She left.'

b. * bəl-beet

in-the-house

'He/She is in the house'

$\begin{array}{llll}\text { c. Paal } & \text { kariim } & \text { Pənna/*Pənno } & \text { bəl-beet } \\ \text { said.3SM } & \text { K. } & \text { that.3SF } & \text { in-the-house }\end{array}$

'Karim said that she is in the house.'

In (33a), a null subject occurs with a verbal predicate inflected for person, number, and gender ( $\varphi$-features). In (33b), a null subject is prohibited; the prepositional predicate doesn't have $\varphi$-features. (33c) is well-formed only when the complementizer ?әnno has $\varphi$-features that identify the embedded null subject.

Turning back to definite relatives, the grammaticality of (34) below indicates that yalli, like Pənno, bears the necessary $\varphi$-features in the context of which null subjects occur. ${ }^{10}$

(34) 1-bənt yalli bəl-beet

the-girl that in-the-house

'The girl that is in the house.'

The prepositional predicate bəl-beet ('in the house') obviously does not show overt subject agreement. If yalli did not agree with the null subject of this predicate, we would expect this sentence to be non-wellformed on a par with (33b), which is contrary to fact.

10 Cross-linguistic data from Standard Arabic provide motivation for the assumption that the definite relative complementizer bears $\varphi$-features, and a case feature as well:

(i) a. ra?aytu 1-waladayni llaDayni tufibbuhuma 1-mufallima saw.1S the-boy.Dual.Acc that.3F.Dual.Acc like.3SF.them(dual) the-teacher 'I saw the two boys that the teacher likes.'

b. 3aa?at 1-fataataani llatani tufibbuhuma 1-mufallima

came.3SF the-girl.Dual.Nom that.3FD.Nom like.3SF.them(dual) the-teacher

'The two girls that the teachers likes came.'

As can be observed in (i) above, the Standard Arabic counterpart of yalli is inflected for person, gender, and number. In addition, the sentences in (i) illustrate that the relative clause complementizer Palla $\mathrm{D}$ displays overt agreement in case with the relativized DP. 
Assume then that the features borne by yalli, i.e., its [+definite] feature and $\varphi$-features, need to be checked in the course of the derivation. ${ }^{11}$

Summarizing, in this section I have discussed the morphosyntactic properties of yalli, the element which introduces definite relatives in LA. I have assumed that:

(35) a. yalli is a complementizer

b. yalli bears the features [+definite], [ $\alpha$ person], $[\beta$ number], and $[\gamma$ gender $]$

c. The features of yalli need to be checked.

It is (35c) that provides the motivation for movement in definite relatives in LA: the necessity to check the features of the complementizer triggers movement in those constructions.

\subsection{Yalli and the nature of the moving element}

This movement can be characterized as covert, i.e. it doesn't involve pied-piping of a category. The moving element is then a bundle of formal features, which include the feature [+definite] and the relevant $\varphi$-features. Within the minimalist theory of Move $\alpha$, the movement of these features will involve adjunction to the complementizer yalli, which heads the relative clause.

The formal features of yalli can only be checked by those of a DP, PPs being obviously not specified for definiteness, as well as $\varphi$-features. This DP cannot be the counterpart of a wh-element: wh-elements are not definite in LA, as shown below.

11 Although the complementizer yalli matches the relativized DP in definiteness, it cannot be said that yalli checks this feature against that of the relativized DP, since yalli can occur in headless relatives, unless headless relatives occur with a non-overt pronominal:

(i) a. bfəbb yalli bəthibbii

like.1S that like.3SF-it

'I like whatever you like.'

b. kariim byilfab maf yalli byil؟ab mafo K. play.3SM with that play.3SM with-him

'Karim plays with whoever plays with him.' 

a.* Payya təlmiiz 1-3diid 'əft
which student the-new saw.2SM
'Which new student did you see?'
b. Payya təlmiiz 3diid 'əft
which student newsaw.2SM
'Which new student did you see?'

Recall that in LA, the adjective and the DP it modifies agree in definiteness. The contrast between (36a) and (36b) indicates that the adjective modifying the wh-phrase Payya təlmiiz (which student) cannot be introduced by the definite article. This contrast shows that wh-phrases are indeed indefinite. Our conclusion is further confirmed by relative clauses modifying wh-phrases. These relative clauses cannot be introduced by yalli:
(37) a.* Payya walad yalli 'əfto raah mbeerif rəzi؟ which boy that saw.2SM-him left.3SM yesterday returned.3SM 1-yom today 'Which boy that you saw leave yesterday returned today?'
b. Payya walad 'əfto raah mbeerih rəziৎ 1-yom which boy saw.2SM-him left.3SM yesterday returned.3SM today 'Which boy that you saw leave yesterday returned today?'

Since relative clauses introduced by yalli can only modify definite relativized DPs, the ungrammaticality of (37a) confirms the non-definite nature of wh-elements in LA.

In brief, the element that checks the features of yalli can be identified as a set of formal features. This set comprises the features [+definite], $\varphi$-features, and case. I identify this set with the null pronominal element pro. pro, like all pronouns in LA, is related to an argument position: in LA, there are no pronouns corresponding to adjuncts. As a consequence, we expect an adjunct not to be relativized in LA, as illustrated by the ungrammaticality of (38). ${ }^{12}$

\footnotetext{
12 In the well-formed phrases (i-iii), the relativized DP corresponds to a prepositional complement within the relative clause.
} 


$$
\begin{aligned}
& \text { a.* ssabab yalli rəft-o ..... } \\
& \text { the-reason that left.1S-it } \\
& \text { 'The reason why I left...' }
\end{aligned}
$$

\subsection{The working of movement and reconstruction in definite relatives}

The discussion so far has provided answers to three of the four questions in (29). Movement in definite relatives was motivated by the need for the relative complementizer to check its [+definite] feature and $\varphi$-features (question (29a)) against those of an element which adjoins to it (question (29c)). The element that checks these features was identified as pro (question (29b)), characterized here as a set of formal features. In the light of this analysis, I examine the working of movement and reconstruction within definite relatives.

\subsubsection{Movement and minimality in definite relatives}

Yalli, which occurs in all definite relatives in LA, bears features which need to be checked by pro. Furthermore, we have noted that in definite relatives, the selective availability of reconstruction indicates that movement is available in those constructions. In other words, to satisfy the morphological requirements of the complementizer yalli the following two scenarios are possible: (i) either pro is moved to COMP (39a) or (ii) pro is directly generated in COMP (39b).

(39) a. ... Definite Relativized $\mathrm{DP}_{\mathrm{i}} \ldots \ldots$. pro $_{i}-$ yalli ........ $\mathrm{RP}_{\mathrm{i}} \ldots \ldots . \mathrm{t}_{\mathrm{i}} \ldots \ldots . . \ldots \ldots \ldots . .$.

b. ... Definite Relativized $\mathrm{DP}_{\mathrm{i}} \ldots . .\left[\right.$ pro $_{i}-$ yalli $\ldots . . . \mathrm{RP}_{\mathrm{i}} \ldots$. pro $\left._{i} \ldots ..\right] \ldots \ldots .$.

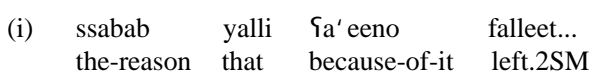

'The reason why you left...'

(ii) 1-maTrah yalli tlaa?ayna fi-i

the-place that met.1P in-it

'The place where we met...'

(iii) TTarii?a yalli fkiitne fiya the-manner that talked.2SM-me(dat.) with-it 'The manner in which you talked to me...' 
In the sentences where the relativized DP is separated from the resumptive pronoun by an island, only the representation in (39b) is available. Since movement of pro is not possible from within an island, the features of yalli can only be checked by generating a null pro directly in COMP. In that case, pro is coindexed with another null pronominal in an argument position within the relative clause. On the other hand, when no island intervenes between the relativized DP and the resumptive pronoun, the representation in (39a) is available for definite relatives, in addition to the representation which doesn't involve movement (39b). In (39a) movement of pro has occurred from within the relative clause to COMP. ${ }^{13}$

The movement analysis sketched in (39a) above raises a question with respect to minimality. Consider constructions such as (40) below, in which the movement of the object pro to yalli crosses the subject pro:

(40) 'əfna [SSuura tabaS təlmiiz-[a $\left.]_{\mathrm{i}_{j}}\right]_{\mathrm{j}}$ yalli kəll mfallmee $_{\mathrm{i}}$ ?aalit saw.1P [the-picture of student.m-her that every teacher said.3sf Pənno pro baddo y\{allə?-[a $]_{j}$ that want. $3 \mathrm{sm}$ hang. $3 \mathrm{sm}$-it

'We saw the picture of her student that every teacher said that he wants to hang it.'

In (40) movement of the object pro to yalli should violate minimality. Indeed, there is a shorter derivation which involves moving the subject pro of the embedded clause instead. In other words, we are lead to expect sentence (40) to be non well-formed, which is not the case.

However, under a theory which takes minimality to be sensitive to the feature being checked (see Chomsky 1995), we can account for the well-formedness of (40). yalli bears the same $\varphi$-features as the relativized DP SSuura taba $\{$ tolmiiza 'the picture of her student'. The pro subject of the embedded verb in (40), being masculine, cannot check those features. Raising pro from the embedded object position to yalli crosses

13 The existence of the two representations in (42) for definite relatives does not raise a question of economy. Assuming that in evaluating derivations for economy, only convergent alternatives with the same numeration are considered, neither (42a) nor (42b) could have a blocking effect on the other, since they don't involve the same numeration: in (42b), pro is selected twice for the initial array whereas, in (42a), it is selected only once (see Aoun and Benmamoun (1998)). 
the embedded subject pro but doesn't violate minimality, since the pro being crossed doesn't bear the relevant $\varphi$-features that need to be checked in yalli.

\subsection{2. pro and reconstruction of definite relativized DPs}

As stated in the previous section, the generation of definite relatives may involve movement (39a) or not (39b). Following Chomsky (1977), Williams (1980) and Borer (1984), I assume that the relative clause and the relativized DP form a predication structure: the relative clause constitutes a complex predicate coindexed with the relativized DP, the subject of this predication. The complex predicate must contain an open position which functions as the predicate variable (the trace in (39a) and pro in (39b) within the definite relative).

We are now in a position to discuss how reconstruction operates within definite relatives. Consider the following English facts (Barss 1986, Hornstein 1984):

(41) His last poem is what every Englishman prefers.

Although the c-command requirement on bound pronouns fails to apply in (41), the pronoun his can still be bound by the QP every Englishman. In (41), the DP his last poem is coindexed with the relative clause via predication. What, which bears the same index as his last poem, can be interpreted as a 'copy' of this DP. Informally, at LF, his last poem, what, and the trace of what within the relative clause, form an extended chain. Hence, the availability of the bound pronoun reading in (41).

Turning to the representations in (39), the relativized DP, the relative clause, and the pro in COMP are all coindexed. However, reconstruction is available in (39a) but not in (39b). In (39a), the pro and its trace form a chain generated by movement. In (39b), the two distinct pro do not form a movement chain. Since reconstruction occurs only with chains generated by movement, reconstruction will be available in (39a) but not in (39b) (see the conclusion for further discussion). 


\subsubsection{Reconstruction of definite relativized DPs}

Having examined how reconstruction of the relativized DP obtains, I now identify the position to which the fronted pro reconstructs.

A close look at definite relatives in LA reveals an asymmetry between preverbal and postverbal subjects with respect to reconstruction. ${ }^{14}$ That is, a pronoun contained in a definite relativized DP can be bound by a preverbal subject QP (42a-43a), but not by a postverbal subject QP (42b-43b).

(42) a. 'əft $\left[\text { SSuura tabå Pəbn- } \mathrm{a}_{\mathrm{i}}\right]_{\mathrm{j}}$ yalli $[\text { kəll mwazzafe }]_{\mathrm{i}}$ saw.1s [the-picture of son-her] that [every employee.f] badda t\{allə? $-a_{j}$ bi-maktab-a want.3sf hang.3sf-it in-office-her 'I saw the picture of her son that every employee wants to hang in her office.'

b. * 'əft [SSuura taba $\left.P \partial b n-\mathrm{a}_{\mathrm{j}}\right]_{\mathrm{j}}$ yalli badda t\{alləP $-\mathrm{a}_{\mathrm{j}}$ saw.1s [the-picture of son-her] that want.3sf hang.3sf-it [kəll mwazzafe $]_{\mathrm{i}}$ bi-maktab-a [every employee.f] in-office-her 'I saw the picture of her son that every employee wants to hang in her office.'

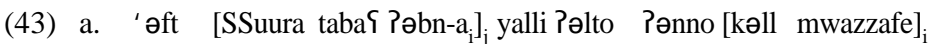
saw.1s [the-picture of son-her] that said.3p that [every employee.f]

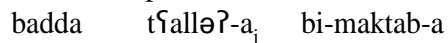
want.3sf hang.3sf-it in-office-her 'I saw the picture of her son that you said that every employee wants to hang in her office.'

b.* 'əft [SSuura tabaf ?əbn- $\left.\mathrm{a}_{\mathrm{i}}\right]_{\mathrm{j}}$ yalli Pəlto Pənno badda saw.1s [the-picture of son-her] that said.3p that want.3sf

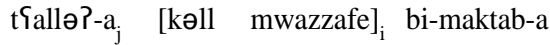
hang.3sf-it [every employee.f] in-office-her 'I saw the picture of her son that you said that every employee wants to hang in her office.'

14 A contrast similar to the one illustrated in (42-43) was first pointed out for Spanish Left Dislocation constructions by Zubizarreta 1993. 
The contrast between (42a) and (43a) on one hand, and (42b) and (43b) on the other, indicates that reconstruction is to a position lower than the preverbal subject, but higher than the postverbal subject position. I assume, along with Aoun and Benmamoun (1998), that this position is within the clitic projection (ClitP) (Sportiche 1992), as in (44) below:

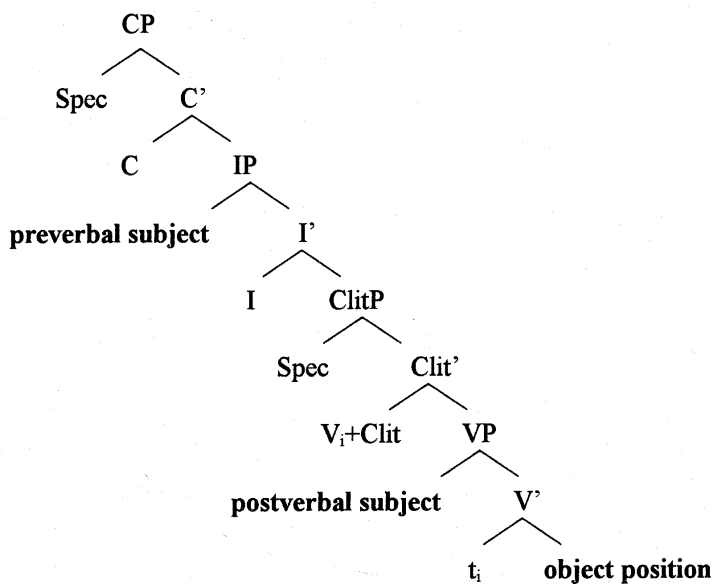

Given the structure in (44), it is clear that reconstruction cannot be to the object position, for instance. If this were the case, this position being c-commanded by both the preverbal and the postverbal subjects, the contrast observed in (42) and (43) would not arise.

The structure in (44) also leads us to expect that, in case the QP subject is generated in a clause higher than the one containing the RP, the preverbal/postverbal subject asymmetry will disappear. This expectation is fulfilled:

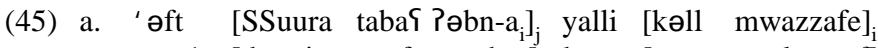
saw.1s [the-picture of son-her] that [every employee.f] Paalit Pənno badda t Sallə $\mathrm{P}-\mathrm{a}_{\mathrm{j}}$ bi-maktab-a said.3sf that want.3sf hang.3sf-it in-office-her 'I saw the picture of her son that every employee said she wants to hang in her office.' 


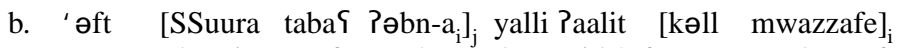
saw.1s [the-picture of son-her] that said.3sf [every employee.f] Pənno badda t\{allə? $\mathrm{a}_{\mathrm{j}}$ bi-maktab-a that want.3sf hang.3sf-it in-office-her 'I saw the picture of her son that every employee said she wants to hang in her office.'

In (45), the bound reading is available: these sentences do not display any preverbal/postverbal subject asymmetry. In both (45a) and (45b), the QP kall mwazzafe 'every employee' and the resumptive clitic occur in different clauses. If pro in (45) reconstructs to the clitic projection, it will end up in a position c-commanded by both the preverbal subject QP (45a) and the postverbal subject QP (45b) of the higher clause.

More generally, in other contexts too pro does not seem to reconstruct below the clitic:

(46) a. Pəmm kariim ${ }_{\mathrm{i}}$ bəthibb-[o $]_{\mathrm{i}}$ mother K. love.3SF-him

'Karim's mother loves him'

b.* bəthibb-[o $]_{\mathrm{i}}$ ?əmm kariim $_{\mathrm{i}}$ love.3SF-him mother K.

'Karim's mother loves him.'

In (46a) but not in (46b), the object and the name Karim contained within the preverbal subject can be coreferential. In (46b), coindexing Karim with the object yields a violation of binding principle $\mathrm{C}$. If the object pro were to reconstruct to the argument position, the sentence in (46b) would be well-formed, like (46a). This is contrary to fact.

We can conclude from the discussion so far that the pro related to an accusative resumptive pronoun cannot reconstruct below the ClitP. Assuming that pro is originally generated in the argument position and that it undergoes A-movement to ClitP, its behavior with respect to reconstruction may be accounted for along the following lines: According to Chomsky (1993), reconstruction is only a property of A'-chains; pro then will only reconstruct to the clitic projection and never below. Alternatively, one may assume that pro, being definite, needs to be interpreted within the clitic projection, outside the VP shell (see Diesing 
(1992), Beghelli and Stowell (1995)). Therefore, at LF, it will not reconstruct to its original position. ${ }^{15}$

\section{Generation of indefinite relatives}

Earlier it was observed that indefinite relatives did not display reconstruction effects (see section 2.2.). Using reconstruction as a diagnostic for the availability of movement, the absence of reconstruction effects in indefinite relatives was interpreted as indicating the absence of movement in those constructions. In other words, restrictive relatives are not systematically generated via movement in LA. Movement is only available for definite relatives. It is motivated by the need to check the definiteness feature and $\varphi$-features of the complementizer yalli. Indefinite relatives lack a complementizer; the motivation for movement is absent in those constructions. Move $\alpha$ being a Last Resort operation (see Chomsky 1995), the generation of indefinite relatives will not involve movement. This accounts for the discrepancy between definite relatives and indefinite relatives with respect to reconstruction effects (question (29d)). ${ }^{16}$

Two possible representations are consistent with the absence of movement in indefinite relatives: either (i) there is a pro directly generated in COMP within the indefinite relative, coindexed with another pro within the relative clause (47a), or (ii) there is no pro in the indefinite COMP and pro occurs only within the indefinite relative $(47 \mathrm{~b}) .{ }^{17}$

15 When a subject gap occurs, I take definite relatives to be represented as follows: (ia) but not (ib) is generated by movement.

(i) a.

Definite Relativized $\mathrm{DP}_{\mathrm{i}}$

...[ pro $_{i}-$ yalli

$\mathrm{X}_{\mathrm{i}}$

$\left[\right.$ pro $_{i}-$ yalli

pro $\left._{i} \ldots . . ..\right]$........

16 For a different analysis assuming that movement is involved in resumption within restrictive relatives, see the important work of Demirdache (1991). In her analysis, restrictive relatives involving resumptive pronouns are all generated by LF-movement of a null operator- identified as pro, to the Spec of Comp. This LF movement, she assumes, does not obey island constraints. An analysis along these lines does not account for the contrast observed between indefinite relatives and definite relatives in LA with respect to reconstruction. Moreover, I have shown that reconstruction, and therefore movement, in definite relatives is indeed sensitive to islands.

17 Recall that the resumptive pro within the indefinite relative provides the predicate variable which is coindexed with the subject of predication, i.e. the relativized DP. Since pro can only be related to an argument position in LA, I can account for the fact that adjuncts cannot 'head' indefinite relatives, as illustrated below: 
(47) a.

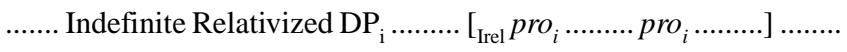

b. Indefinite Relativized $\mathrm{DP}_{\mathrm{i}}$

pro $_{i}$ ..........

\section{Conclusion: the raising analysis revisited}

In this paper, we have examined the properties of restrictive relatives in LA. We have found the following generalizations to hold true of these constructions:

(48) a. Restrictive relatives in LA are always generated with a resumptive element.

b. Restrictive relatives in LA are not sensitive to island constraints.

c. Definite restrictive relatives may display reconstruction effects only when the resumptive element does not occur within an island.

d. Indefinite restrictive relatives do not display reconstruction effects.

e. The definite relative COMP is always in a checking relation with pro.

f. pro cannot occur in the COMP of indefinite relatives.

g. Adjuncts cannot be relativized in LA.

To account for the above generalizations, I have argued for the following analysis:

(49) a. In definite relatives, the features of the complementizer yalli, $\{[+$ definite $], \phi$-features, case $\}$ enter into a checking relation with pro.

b. This pro can be directly generated in relative COMP, or (covertly) moved to COMP in definite relatives.

c. In indefinite relatives, pro need not and therefore does not move to COMP (Last Resort).

(i)* STiine sabab rəfto

give.3S-me reason left.2SM-it

'Give me a reason why you left.'

The sentence in (i) contrasts with the one in (ii) below where the head of the relative is related to the complement position of a preposition:

(ii) STiine Pəsm mafall nəmto fi-i give.2SM name place slept.1P in-it 'Give me the name of a place where you slept.' 
In both indefinite and definite relatives, the relativized DP ends up coindexed with a pro. Since pro can only be related to argument positions, it follows that adjuncts in LA cannot be relativized, as seen in (41), repeated here for convenience, and in (50):

$$
\begin{aligned}
& \text { (41)* ssabab yalli rəft-o ..... } \\
& \text { the-reason that left.1S-it } \\
& \text { 'The reason why I left...' } \\
& (50) * \text { sabab rəht-o ..... } \\
& \text { the-reason left.1S-it } \\
& \text { 'A reason why I left...' }
\end{aligned}
$$

As a final discussion, I would like to reconsider the working of reconstruction in definite relatives generated by movement. To account for the fact that a definite relativized DP can be interpreted with respect to a position within the relative clause, I assumed that this relativized DP, the fronted pro and its trace, form an extended chain (see section 3.3.2.). One might suggest an alternative analysis which can account for the reconstruction effects observed in definite relatives, in a more straightforward fashion; that is, the raising analysis argued for in Vergnaud 1974, 1985 and more recently in Kayne 1994. If the relativized DP is itself fronted from within the relative clause to check the necessary features of yalli, the reconstruction effects are to be expected. In the cases where movement cannot be involved, i.e. when the relativized site occurs within an island or when it corresponds to an indefinite DP, the relativized DP is directly generated in its surface position, coindexed with a null pro in the relativized site and no reconstruction occurs.

Under a raising analysis of the relativized DP, the obligatoriness of resumptive elements within definite relatives remains unaccounted for: if it is the relativized DP, and not pro, that raises to COMP, why is it necessary for the relative clause to contain a resumptive clitic in object positions? Why can't a gap occur in these positions?

As can be seen in the following examples, a DP in LA can be topicalized (51a) or clitic-left dislocated (51b). In (51a), the DP is coindexed with a gap, and in $(51 b)$, with a resumptive clitic: 
(51) a. 1-walad zz2iir 'əft mbeerif the-boy the-little saw.1S yesterday

'The little boy, I saw yesterday.'

b. 1-walad zz2iir ' əft-o mbeerih the-boy the-little saw.1S-him yesterday 'The little boy, I saw him yesterday.'

Similarly, wh-elements in LA may be fronted and coindexed with a gap (52a) or a resumptive clitic (52b):
a. Payya walad 'əft e mbeerif which boy saw.2SF yesterday
'Which boy did you see yesterday?'
b. Payya walad 'əft i-i mbeerif which boy saw.2SF-him yesterday 'Which boy did you see yesterday?'

Why is it then that definite relativized DPs cannot be coindexed with a gap? Under an analysis which considers that the relativized DP itself raises in definite relatives, the answer is not obvious. However, under an account that assumes pro raising to COMP, the answer is rather straightforward: pro in object positions is always generated with a clitic, as evidenced by the ungrammaticality of (53b), below:

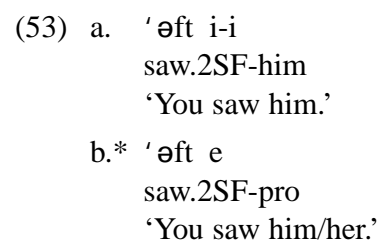

The ungrammaticality of a definite relativized DP coindexed with a gap in LA (54) reduces to the ungrammaticality of (53b):
(54)* 1-walad yalli 'əfte ...... the-boy that saw.2SF
'The boy that you saw .....'


In the same vein, I argued that adjuncts in LA cannot be relativized because pro cannot be generated in non-argument positions. Once again, under a raising analysis of the relativized DP, it is not clear how to exclude sentence (41) in LA, given the well-formedness of the English sentence in (55):

(55) I know the reason why John left.

Thus, (definite) relatives in English differ from the definite relatives in LA, in at least the following respects:

(56) a. Relatives in English can involve movement of a relative element which can be a bare wh-element (ia) or a wh-element embedded within a prepostional phrase (ib):

(i) a. The book which Bill wrote

b. The table under which he is hiding

b. An adjunct in English can be relativized:

(ii) a. the reason why John left

b. The place where we met

In LA, wh-elements are indefinite (see section 3.2.) and thus cannot co-occur in COMP with the definite relative complementizer yalli. Since only pro can be fronted to COMP in definite relatives, only arguments can be relativized.

In brief, the difference between relative clauses in English and Lebanese Arabic may be accounted for in case Vergnaud's raising analysis is adopted for English and the pro raising analysis is adopted for LA. ${ }^{18}$

18 A similar proposal is put forward by Demirdache (to appear) to account for the following facts; Doron (1982) and Sells (1984), indicate that restrictive relatives with gaps (as in English) differ from restrictive relatives with RPs (as in Hebrew) in their interpretation:

(i) a. Dani yimca Pet ha- $\mathrm{i}^{\prime} \mathrm{a}_{\mathrm{i}}$ ' $\mathrm{e}$ hu mexapes $\mathrm{t}_{\mathrm{i}}$ D. will-find Acc the-woman that he seeks

'Dani will find the woman that he seeks.'

b. Dani yimca Pet ha-Pi' $a_{i}$ 'e hu mexapes ota D. will-find Acc the-woman that he seeks her 'Dani will find the woman that he seeks.' 


\section{REFERENCES}

Aoun, J. (1993) The Syntax of Doubled Arguments. International Journal of Basque Linguistics and Philology 27, 709-730. \& E. Benmamoun (1998) Minimality, Reconstruction, and PFMovement. Linguistic Inquiry 29: 569-597. \& Y.-H. A. Li (1990) Minimal Disjointness. Linguistics 28: 189203.

\& L. ChoueIRI (1996) Resumptive epithets. Ms., University of Southern California, Los Angeles, California.

BARss, A. (1986) Chains and Anaphoric Dependence: On Reconstruction and Its Implications. Doctoral Dissertation, MIT, Cambridge, Mass.

Beghelli, F. \& T. Stowell (to appear) Distributivity and Negation. In Ways of Scope Taking. Anna Szablocsi (ed.). Boston: Kluwer Academic Publisher.

Borer, H. (1984) Restrictive Relatives in Modern Hebrew. Natural Language and Linguistic Theory 2, 219-260.

(ia) is ambiguous between a specific and a non-specific reading of the relativized head $h a-P^{i}{ }^{\prime} a$ ('the woman'). That is, (ia) can be used in a context where Dani is looking for a woman who has a certain property, but he doesn't know her identity yet (non-specific reading). (ia) can also be used in a context where Dani is looking for a specific woman, say, Rina. (ib), on the other hand, is unambiguous; it has only the interpretation where the relativized head

$h a-$ Pi' ('the woman') refers to a specific person, whose identity is known to Dani.

Demirdache (to appear) accounts for the contrast between (ia) and (ib) by assuming Vergnaud's raising analysis for (ia) and pro raising for (ib).

However, the facts described above for Hebrew do not carry over to LA: in LA, the equivalent of (ib), below, is ambiguous. It is interpreted as (ia).

(ii) saami raf ylee?e 1-mara yalli $\left\{a m\right.$ ynabbi“ ${ }^{\prime}$ Salaya S. will find the-woman that Asp look.3SM for-her

'Sami will find the woman that he is looking for.'

LA, unlike Hebrew, does not allow gaps in object position within headed restrictive relatives. In LA, a contrast similar to the one in (i) seems to exist only when an alternation between gaps and resumptive pronouns is available. This is the case with wh-interrogatives:

(iii) a. Payya walad rah t?aaSiS 1-mfallme

which boy fut. punish the-teacher

'Which boy will the teacher punish?'

b. Payya walad rah t?aaSiS-o l-mfallme

which boy fut. punish-him the-teacher

'Which boy will the teacher punish?'

(iiia) is ambiguous but not (iiib). (iiib) admits only a specific reading. 
Bresnan, J. \& J. Grimshaw (1978) The Syntax of Free Relatives in English. Linguistic Inquiry 9, 331-391.

Chomsky, N. (1977) On Wh-Movement. In P. Culicover, T. Wasow, and A. Akmadjian (eds.) Formal Syntax. New York: Academic Press. (1993) A Minimalist Program for Linguistic Theory. In: The View from Building 20: Essays in Linguistics in Honor of Sylvain Bromberger, eds. Kenneth Hale and Samuel Jay Keyser, 1-52. Cambridge, Mass.: MIT Press.

(1995) The Minimalist Program. Cambridge, Mass.: MIT Press. Cinque, G. (1990) Types of A'-Dependencies. Cambridge, Mass.: MIT Press.

DemiRdache, H. (1991) Resumptive Chains in Restrictive Relatives, Appositives, and Dislocation Structures. Doctoral Dissertation, MIT, Cambridge, Mass.

Diesing, M. (1992) Indefinites. Cambridge, Mass.: MIT Press.

Doron, E. (1982) On the Syntax and Semantics of Resumptive Pronouns.

In Texas Linguistics Forum 19, ed. R. Bley-Vroman, 1-48. Austin, Texas.

EID, M. (1977) Arabic Relativization: Shadow Deletion or Pronoun Drop? Minnesota Papers in Linguistics and Philosophy of Language 4, 19-31.

(1983) On the Communicative Function of Subject Pronouns in Arabic. Journal of Linguistics 19, 287-303.

Engdhal, E. (1986) Constituent Questions. Dordrecht: D. Reidel Publishing Company.

Fassi Fenri, A. (1982) Linguistique Arabe: Forme et Interprétation.

Rabat: Publications de la Faculté des Lettres et Sciences Humaines. Georgopoulos, C. (1989) Syntactic Variables: Resumptive Pronouns and A'-Binding in Palauan. Doctoral Dissertation, University of Utah. HornsteIn, N. (1984) Logic as Grammar. Cambridge, Mass.: MIT Press. Horvath, J. (1986) FOCUS in the Theory of Grammar and the Syntax of Hungarian. Dordrecht: Foris Publications.

Kato, M. (1999) Strong and Weak pronominals in the Null Subject Parameter. Probus 11: 1-37.

KaYne, R. (1984) Connectedness and Binary Branching. Dordrecht: Foris Publications.

Mccloskey, J. (1979) Transformational Syntax and Model-Theoretic Semantics: A Case Study in Modern Irish. Dordrecht: Reidel. 
(1990) Resumptive Pronouns, A'-Binding, and Levels of Representation in Irish. In Syntax and Semantics of the Modern Celtic Languages, Syntax and Semantics 23. New York: Academic Press.

Montalbetti, M. (1984) After Binding: On the Interpretation of Pronouns. Doctoral Dissertation, MIT, Cambridge, Mass.

Reinholtz, C. (1993) Verb Second, Mood, and Operator Licensing. Ms., USC, Los Angeles, California.

SAFIR, K. (to appear) Derivation, Representation and Resumption: The Domain of Weak Crossover. Linguistic Inquiry.

SElls, P. (1984) Syntax and Semantics of Resumptive Pronouns. Doctoral Dissertation, University of Massachusetts at Amherst, Amherst, Massachusetts.

Shlonsky, U. (1992) Resumptive Pronouns as a Last Resort. Linguistic Inquiry 23, 443-468.

Sportiche, D. (1992) Clitic Constructions. Ms., UCLA, Los Angeles, California.

Vergnaud, J-R. 1974. French Relative Clauses. Doctoral Dissertation, MIT, Cambridge, Massachusetts. 1985. DJpendences et Niveaux de ReprJsentation en Syntaxe. Amsterdam: John Benjamins.

Williams, E. 1980. Predication. Linguistic Inquiry 11, 203-238.

Zaenen, A., E. Engdahl \& J. Maling. (1981). Resumptive Pronouns Can Be Syntactically Bound. Linguistic Inquiry 12, 679-682. 
